\title{
Interview with Alan Maley on Teaching and Learning Creative Writing
}

\author{
Interviewed by Ruzbeh Babaee \\ Faculty of Modern Languages and Communication, Universiti Putra Malaysia
}

Received: -

doi:10.7575/aiac.ijclts.v.3n.3p.77
Accepted: -

Published: 31-07- 2015

\section{Introduction}

Alan Maley is a British, award-winning, internationally-known writer and artist, highly regarded for his unique observation of life at the turn of the century. He has been involved in English Language Teaching (ELT) for over 50 years. He worked for the British Council in Yugoslavia, Ghana, Italy, France, China and India and was the Director of the Bell Educational Trust in Cambridge for 5 years. He later worked in universities in Singapore, Thailand, Malaysia and UK. Alan has published over 40 books and numerous articles. In the following, Dr. Maley answered our questions on teaching creative writing in academic centers, the relationship between creative writing and language learning, and the status of creative writing in non-English speaking countries.

\section{The Interview}

\section{$R^{1}$ : What is your definition of creative writing?}

$\mathbf{A M}^{2}$ : Any kind of writing which has an aesthetic or affective rather than a purely pragmatic intention or purpose. So of course that would include poetry and fiction. But I would also include journal writing, essays on all aspects of life, and letters, including e-mails, blog posts and Tweets and Facebook entries of the non-trivial kind.

In fact, I believe all writing has the potential to be creative. Even when writing book reviews or articles for journals or book chapters for professional publications I am acutely aware of the need to find my own individual voice. All too often we are intimidated by the so-called conventions of academic writing. This can lead to the desertification of the language we use. We should never forget that real writing, whether creative or academic, is intended for a reader. And why should our reader be forced to read something arid, tedious and without interest? If we have something relevant and interesting to say, we should write about it in an accessible and interesting way. If we do not do this, we risk anaesthetizing our readers!

\section{RB: Why is it important to study creative writing in academies?}

AM: Let me answer this in two parts, because I think there are two questions wrapped up in one here.

1. I think creative writing is important for learners for the following reasons:

- It can give a real boost to the learners' self-esteem when they realise that they can write about things which are important to them in the target language. 'Wow! I wrote that! And I wrote it in English!' This is why we should always try to 'publish' what they write - by displaying it on a board, by having it performed, or by making small booklets, or posting it on a class web-page.

- It gives them permission to 'play' with the language they are learning, without the fear of reproof. Playfulness is a seriously neglected aspect of learning. We need to play around with the language in order to find out what works and what doesn't, how far we can go in stretching the vocabulary and structures of the language. If we do not engage in playful activities, we do not make mistakes - and it is through our mistakes that we learn. If we never make a mistake, our learning is seriously impaired.

- It helps learners develop the skills they will need later - especially close observation. Most of the time, in this age of instant and constant distraction, we do not really notice the things around us. But in order to write well, we need to be acutely aware of the world and what it contains. This enhanced awareness of people, places, things, feelings, sensations, language, and incident is key for living as well as writing.

- Creative writing has the capacity to engage learners in a deeper level of psychological processing than many other activities. When writing creatively, we can draw on the full range of our memories, our observations,

\footnotetext{
${ }^{1}$ Ruzbeh Babaee

${ }^{2}$ Alen Maley
} 
our feelings, our thoughts, our dreams....It is a truly holistic experience. As Craik and Lockhart showed in their experiments in the 1970 's, the greater the depth of processing, the better the learning and the longer people retain what they have learnt.

- Because it can be so totally absorbing, creative writing often gives rise to what Csikszentmihalyi calls 'Flow' experiences. When we are in a flow state, we forget about everything except the focus of our engagement. We are lost in the experience. And when in a flow state, we learn better.

- It is motivating, not just because it enhances self-esteem but also because it can be enormously enjoyable. Enjoyment is all too rarely associated with teaching and learning, yet without it, the quality of the learning experience is seriously impaired.

2. The second part of my answer relates to teachers and academics. I feel that engaging with creative writing, either through teaching it to students or simply by doing it has a number of advantages for teachers:

- It helps to keep our English fresh and alive. As teachers of English at whatever level, and whether or not we are 'Native Speakers', we are mostly exposed to a diet of rather bland and controlled textbook English, and of various forms of defective or low-level English from our students. If this is all we get, our own English is likely to get rusty. At the very least it will not go on growing, and at the worst it will begin to resemble the English level of our students. Creative writing offers us opportunities to keep it vibrant and flourishing.

- When we start to get involved with creative forms of writing, I believe this makes us more interested in our lives and in the world we live in. That makes us more interesting as people. And, strangely enough, students tend to prefer their teachers to be interesting people.

- When we teach creative forms of writing, I believe that we also begin to understand better how such texts are composed. We become more aware of the process of writing. And this gives us better insights into teaching writing of all kinds - including expository writing. It may even encourage us to help our students to write expository texts with some sap and flavor to them!

- It is important for us as teachers of creative writing to be seen to be writers ourselves. There is no point in exhorting our students to write, if we ourselves do not write too. We are inevitably role models for our students. Students learn their teachers, not just what they teach. Part of a poem I wrote once goes like this:

Our students learn their teachers

Not only the things they teach -

So let's be sure we practice

What we preach.

\section{RB: Do creative writing activities develop language skills of the students?}

AM: They do. In particular, they help students acquire a richer vocabulary, and to consolidate and maintain it. I believe it also helps them develop a more discriminating use of vocabulary - why this word and not that? What is the collocation which works best for this word? And so on. They also begin to experiment with the syntactical limits on the language they are learning. In addition, I believe they often gain a better control over the phonological resources of the language. Creative writing needs to sound right, not just look right. This means they have to pay attention to the cadences and heartbeat of the language - not just the phonemes. Creative writing encourages them to develop this 'feel' for what sounds right.

\section{RB: Do teachers and students have to follow a particular approach for creative writing?}

AM: No, I don't think so. There is no right way to teach creative writing. The main thing is to have them write a lot, and to give them the necessary support in terms of the way tasks are set up and the way feedback is given.

I have suggested elsewhere that teachers need to put in place the right basic conditions. There are a number of general points which will help make implementing creative writing activities more likely to succeed:

- Try to establish a relaxed, non-judgmental atmosphere, where your students feel confident enough to let go and not to worry that their every move is being scrutinized for errors.

- Ensure that the students' work is 'published' in some way. This could be by simply keeping a large noticeboard for displaying the students' work. Other ways would include giving students a project for publishing work in a simple ring binder, or as part of a class magazine. Almost certainly, there will be students able and willing to set up a class website where work can be published. Performances, where students read or perform their work for other classes or even the whole school, are another way of making public what they have done.

- Encourage students to discuss their work together in a frank but friendly manner. We get good ideas by bouncing them off other people. Help them establish an atmosphere where criticism is possible without causing offence.

- Explain regularly how important accurate observation is, and encourage 'noticing' things. They also need to be encouraged to be curious and to follow up with 'research' - looking for more information, whether in books, on the Internet or by asking people. 
- Make it clear that what they do in the classroom is only the tip of the iceberg. To get real benefit from these activities, they need to do a lot of work outside class hours. Most of what we learn, we do not learn in class. You can capitalize on that fact.

- Do the activities regularly in order to get the best effects. Maybe once a week is a sensible frequency. If you leave too long between sessions, you have to keep going back to square one. That is a waste of time and energy.

RB: The conventional idea is that writers are born and some people question if creative writing can be taught. Do you deconstruct this established belief with the purpose of teaching creative writing in your classes?

AM: Obviously, some people have a greater aptitude for writing then others. But I do not believe that writers are born (with the possible exception of some geniuses). We all have creative potential. I agree with Ron Carter's assertion that 'linguistic creativity is not simply a property of exceptional people but an exceptional property of all people.' And right from the start I tell my students this. And throughout a course I will reiterate it, and demonstrate its truth by reading parts of the creative texts the students have written. One of the teacher's key roles is to support and encourage the students in their efforts to write original texts. The key word is 'encouragement'. That means not offering indiscriminate and unjustified praise but quietly and firmly helping the student realise what is worthwhile and what can be improved.

RB: In 2003, you founded The Asian Teacher-Writer Group, with the idea that Non-Native Speaker Teachers in Asia are capable to produce literary works. Can you tell us about that group? Its goals, achievements, status...

AM: Actually, I co-founded the group. It arose from a Creative Writing module I had developed for the MA in English Language and Literature at Assumption University, Bangkok. One of my colleagues, Dr Tan Bee Tin had asked if she might sit in on the course. She suggested that we might organize a small workshop/conference at Assumption, inviting colleagues from around the region. One of those who took part was Dr Jayakaran Mukundan from UPM. He saw the potential of this kind of work and organized our next meeting, in Melaka in 2004. And we went on from there. Since then we have had at least one workshop/conference every year, held in a different Asian country each time. We normally have three days of intense writing and peer reviewing for the group, including one day on a writing trip in the locality. We also offer conference papers and workshops to the local sponsoring university or organization in order to introduce and encourage creative writing among local teachers. We normally publish the best of our writing - to date we have about 15 small books of our writings in published form.

The great strength of the group is its independence. We are a voluntary group of like-minded professionals, unattached, and therefore unfettered by any institutional affiliation. But this is also our greatest weakness, as we have no financial base, and must depend on sponsorship from institutions in whichever country in the region. So far we have survived for 13 years but it is a precarious existence.

The aims and beliefs of the group I have set out elsewhere:

The group operates in the belief that NNS teachers are not only capable of but are also uniquely well-placed to write literary materials for use by their own and other students in the Asia region. By virtue of the fact that they share their students' backgrounds and contexts, they have an intuitive understanding of what will be culturally and topically relevant and attractive for them. This is in stark contrast to many of the reading materials published for the global market, which are often remote from the students' lived experience and interests. What many NNS teachers all too often lack is the confidence in their own ability to write interesting material. The group operates to dispel this misconception.

The following rationale underpins the activities of the group:

- A belief in the value of creative writing in English both for teachers and for students.

- A belief in the ability of teachers in the region to produce their own English teaching materials.

- A belief that these materials will provide useful input for promoting reading (and other activities) in English.

- A belief in the value for professional and personal development of forming a closely-knit, Asia-wide, mutually-supportive learning community of teacher/writers.

The objectives are:

- To produce poetry and stories appropriate in level and content for use by Asian students of English at secondary level.

- To publish and promote these as widely as possible, thus creating a wider awareness of the value of CW.

- To develop materials and activities for the teaching of creative writing.

- To run creative writing conferences and workshops for the wider teaching community wherever possible.

- In this way, to boost the self-esteem and confidence of teachers of English in Asia. 
RB: How do you compare the literary works written by bilingual writers such as K. S Maniam or Indians, Chinese with native English writers? Do not you think that the literary works written by natives are superior to those produced by bilingual writers?

AM: When I started my career back in the 1960's there were relatively few writers in English whose first language was not English. I have been fortunate to have lived through one of the most fascinating and fertile periods of change and development of literature in English. I was at the University of Leeds when it was promoting what was then called 'Commonwealth Writing'. It was this which first put me in touch with the first flowering of writers from the Caribbean, from the Indian sub-continent and from Africa, especially West Africa. I was subsequently lucky to work in Ghana for 5 years at a time of intense activity on the literary front in West Africa. Later still, I was working in India at a time when more and more writers of quality were emerging and being published. To get some idea of the expansion of Indian writing alone, when Penguin India started their list (around 1986?) there were no more than a handful of titles. Go on line and see just how many there are now.

So there has been an great expansion both of writers in these former colonial territories but also of literature written by people who have left those countries and now live in the west. This has led to a kind of double-visioned writing, looking both ways at once, which is interesting in its own right. And with the spread of English as a global medium of communication, we have also seen original books in English (not translations) coming out of China, Iran, Thailand and Vietnam. This is quite a new phenomenon.

To return to your question, I do not see how a writer's place of origin is in any way linked to the quality of what they write. Some of the greatest publishing successes in recent years have come from writers whose first language was not English: Vikram Seth's A Suitable Boy, Arundhati Roy's The God of Small Things, Tan Twan Eng's The Garden of Evening Mists, Khaled Hosseini's The Kite Runner, to mention only a few. What we need to look for is the quality of the writing, not the provenance of the writer. Of course, there is plenty of rubbish too - but that goes for publishing in general. And there are disadvantages in too easy success attributed to the exoticism of the settings and characters. But we have in contemporary English literature probably the most varied and richest resources of any language. And that is something to celebrate.

RB: You have taught in several universities in Singapore and worked in South Asia for a long time. How do you evaluate the capacities for creative writing in this region of Asia?

AM: As I have suggested above just now, I believe there is a great potential for creative writing in English in the region. My hope is that this will develop hand in hand with writing in the languages of the region. English is a wonderful language - but so are all languages. It would be a pity of the spread of English were to suffocate the smaller languages.

\section{RB: You have been teaching creative writing for many years. What is your suggestion to aspiring writers?}

AM: No advice I give would be useful in all circumstances. But here are a few very simple things which have worked well for me:

- Write, don't just talk about it! Write every day. Don't listen to the excuses your sub-conscious will whisper in your ear.

- Read a lot. Read books about writing (there are a few suggestions below) but remember that you can't learn to write just by reading about it - you have to write too! But also read books about anything. We absorb a lot unconsciously when we read. Give your mind plenty to think about.

- Experiment with lots of different topics and different genres. If you have never written a poem, write one. If you have never written a short story, write one. If you have never written about flowers, or horses, or spiders, or washing powder or stamp collecting, etc - try writing about them. Don't limit yourself to just one kind of writing.

- Keep a notebook and take it with you everywhere. Note down anything that might feed into your writing later. If you don't write it down, you will surely forget it.

- Try to develop a routine which suits your personality and other demands on your time. When do you write best - morning or night or...? What kind of materials do you like to use to write with? Is there a room or corner where you feel at home and where ideas come more easily to you?

- Talk to people who are interested in writing or in what you have written. But make sure they are people you can trust - to tell you the truth about your writing, and not to use it as a weapon against you among your other friends. It is always a good idea to get another opinion about your writing: it is far easier to spot someone else's faults than it is to spot your own.

- Be kind to yourself. If you miss a deadline, or get blocked and frustrated with yourself, let go. There is no point in beating yourself over the head. The only person who suffers is you. We punish ourselves too much. Do something else that will take your mind off your feelings of inadequacy: go for a walk, go out for a meal with a friend, read a book, watch a video ... anything will do.

And good luck in all your writing! 
Some Suggested Readings

Arnold, J. (1999). Affect in Language Learning. Cambridge: Cambridge University Press.

Carter, R. (2004) Language and Creativity: the art of common talk. London: Routledge.

Cook, G. (2000) Language Play: Language Learning. Oxford: Oxford University Press.

Craik, F.I.M. and R.S. Lockhart (1972) 'Levels of processing: a framework for memory research.' Journal for verbal learning and Verbal Behaviour II: 617-84.

Crystal, D. (1998) Language Play. London: Penguin.

Fry, S. (2007) The Ode Less Travelled. London: Arrow books

Godberg, N (1986) Writing Down the Bones_ Boston and London : Shambhala Pubs.

Koch, K. (1990) Rose, where did you get that red? New York: Vintage Books.

Maley, A. (ed) (2007 a)) Asian Short Stories for Young Readers. Vol. 4. Petaling Jaya: Pearson/Longman Malaysia

Maley, A. (ed) (2007 b)) Asian Poems for Young Readers. Vol.5. Petaling Jaya:Pearson/Longman Malaysia.

Maley, A. and J. Mukundan. (eds) (2005 a)) Asian Stories for Young Readers, Vol 1_ Petaling Jaya: Pearson/Longman Malaysia.

Maley, A. and J. Mukundan (eds) (2005 b) Asian Stories for Young Learners. Vol. 2 Petaling Jaya: Pearson Malaysia Maley, A. and J. Mukundan (eds) (2005 c) Asian Poems for Young Readers.Vol. 3. Petaling Jaya: Pearson/Longman.

Maley, A. and J. Mukundan (2011 a) Writing Poems: a resource book for teachers of English. Petaling Jaya: Pearson Malaysia

Maley, A. and J. Mukundan (2011 b) Writing Stories; a resource book for teachers of English. Petaling Jaya: Pearson Malaysia.

Maley, A. (2012) Creative Writing for Students and Teachers. HLT mag. Year 14. June 2012.

McRae, J. (1991) Literature with a Small ' $l$ ’. Oxford.: Macmillan.

Matthews, P. 1994. Sing Me the Creation. Stroud:Hawthorn Press.

Mukundan, J. (ed) (2006) Creative Writing in EFL/ESL Classrooms II. Petaling Jaya: Pearson Longman Malaysia

Spiro, J (2004) Creative Poetry Writing. Oxford: Oxford University Press.

Spiro, J. (2007) Creative Story-building. Oxford: Oxford University Press.

Tan, B. T. (ed) (2004). Creative Writing in EFL/ESL Classrooms I_ Serdang: UPM Press.

Wright, A. and D. Hill. (2008) Writing Stories. Innsbruck: Helbling Languages. 